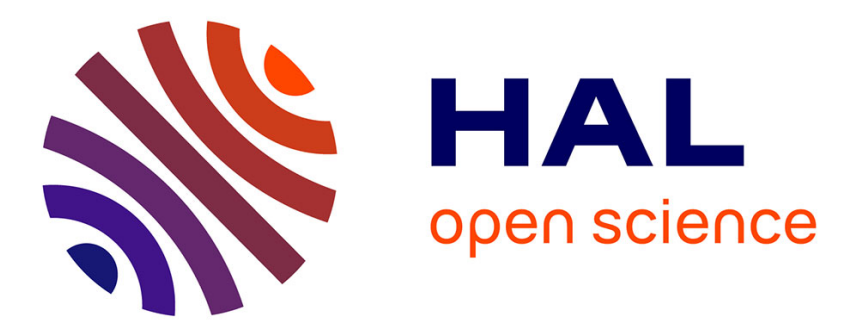

\title{
Composted and formulated poultry litters promote soil nutrient availability but not plant uptake or edamame quality
}

Reina Blair, Mary Savin, Pengyin Chen

\section{- To cite this version:}

Reina Blair, Mary Savin, Pengyin Chen. Composted and formulated poultry litters promote soil nutrient availability but not plant uptake or edamame quality. Agronomy for Sustainable Development, 2014, 34 (4), pp.849-856. 10.1007/s13593-014-0206-9 . hal-01234827

\section{HAL Id: hal-01234827 \\ https://hal.science/hal-01234827}

Submitted on 27 Nov 2015

HAL is a multi-disciplinary open access archive for the deposit and dissemination of scientific research documents, whether they are published or not. The documents may come from teaching and research institutions in France or abroad, or from public or private research centers.
L'archive ouverte pluridisciplinaire HAL, est destinée au dépôt et à la diffusion de documents scientifiques de niveau recherche, publiés ou non, émanant des établissements d'enseignement et de recherche français ou étrangers, des laboratoires publics ou privés. 


\title{
Composted and formulated poultry litters promote soil nutrient availability but not plant uptake or edamame quality
}

\author{
Reina M. Blair • Mary C. Savin • Pengyin Chen
}

Accepted: 16 January 2014 / Published online: 13 February 2014

(C) INRA and Springer-Verlag France 2014

\begin{abstract}
Poultry litter can be a beneficial organic fertilizer if managed properly. Treating poultry litter can impact litter decomposition and nutrient release after application to soil. Knowledge about potential benefits to soil and crop quality from formulated pelletized or composted poultry litter amendments is limited. Few studies have focused on legumes and value-added crops such as edamame soybean. Here, we conducted greenhouse and field experiments in northwest Arkansas to investigate the effects of a composted and two formulated poultry litters applied at a $112 \mathrm{~kg} \mathrm{P} \mathrm{ha}^{-1}$ on nutrient availability and enzyme activities in a silt loam soil growing edamame. Litters were incorporated pre-plant, and soil parameters were monitored throughout the growing season. Plant nutrient concentrations and seed composition were measured at reproductive stages. Our results show that the composted litter and the two formulated litters have similar $\mathrm{P}$ content equivalent to about $5 \% \mathrm{P}_{2} \mathrm{O}_{5}$. Both litters increased Mehlich-3 and water soluble $\mathrm{P}$ in soil, with soluble $\mathrm{P}$ concentrations ranging from 33 to $316 \%$ over the control. Dissolved organic $\mathrm{C}$ and inorganic $\mathrm{N}$ increased in the field following application of formulated poultry litter but not following application of composted poultry litter. Plant N and P uptake and seed nutritional value were not significantly increased by poultry litter addition. We conclude that composted poultry litter may be a better alternative for edamame production than formulated litters because it adds a more stable organic substrate to soil.
\end{abstract}

R. M. Blair $\cdot$ M. C. Savin $(\bowtie) \cdot$ P. Chen

Department of Crop, Soil, and Environmental Sciences, University of Arkansas, 115 Plant Science Building, Fayetteville, AR 72701, USA e-mail: msavin@uark.edu

Present Address:

R. M. Blair

P. O. Box 1303, Tegucigalpa, D.C, Honduras
Keywords Formulated pelletized poultry litter $\cdot$ Compost . Edamame $\cdot$ Soybean $\cdot$ Crop quality $\cdot$ Soil quality

\section{Introduction}

Finding appropriate post-animal-operation treatments so that poultry litter can be used as a valuable organic matter and nutrient source in agroecosystems without causing non-point source pollution is imperative for sustainability in rural, agricultural areas. Similar to other states in southeastern USA, Arkansas has a concentration of confined animal feeding operations that generate considerable amounts of poultry litter. In 2011, Arkansas ranked second nationwide in broiler production, raising over one billion broiler chickens with a value of approximately $\$ 2.8$ billion (USDA-NASS 2012). Benton and Washington, two adjacent counties in northwest Arkansas, produce over half of all broilers in the state, yielding over 100,000 metric tons of excess litter annually (Young et al. 2005). In the past, poultry litter has been applied as a soil amendment to pasture land (Watts and Torbert 2011) and nonlegume crops such as rice (e.g., Golden et al. 2006; Wild et al. 2011). Land applications of poultry litter for nitrogen (N) fertilization needs have resulted in high soil test phosphorus (P) levels, increasing potential for $\mathrm{P}$ loss and raising concerns about non-point source pollution in surface- and groundwater (Pederson et al. 2002; Sharpley et al. 2004). Thus, alternative management practices for land application of poultry litter need to be identified and established.

Arkansas ranked first in the south and tenth nationally in soybean [Glycine $\max (\mathrm{L}$.) Merr.] production (Arkansas Soybean Promotion Board 2011). Soybean production is concentrated in eastern Arkansas, but more than $66 \%$ of counties in the state produce soybeans, with average yields of approximately 2,628 kg ha ${ }^{-1}$ (Arkansas Soybean Promotion Board 2011). The $P$ content of poultry litter makes it desirable for 
soybean, which often requires $\mathrm{P}$ fertilization to maximize yield, thus being a beneficial crop for utilizing $P$ added to soil from poultry litter applications (Nass et al. 2003; Slaton et al. 2009). Approximately $0.9 \mathrm{~kg} \mathrm{P}_{2} \mathrm{O}_{5} \mathrm{ha}^{-1}$ or $0.39 \mathrm{~kg} \mathrm{Pha}^{-1}$ are removed per bushel of soybean harvested (Slaton et al. 2003). In Arkansas, the average $\mathrm{N}: \mathrm{P}_{2} \mathrm{O}_{5}: \mathrm{K}_{2} \mathrm{O}$ ratio in poultry litter is approximately $3: 3: 2.5$, and an estimated $90-100 \%$ of the $\mathrm{P}$ is inorganic or plant available during the first growing season (Espinoza et al. 2007). There are economic incentives in using poultry litter as an alternative $\mathrm{P}$ fertilizer due to increasing costs of commercial fertilizers (Slaton et al. 2009), but its use in legume crops, including soybean, often has been discouraged as it may reduce symbiotic $\mathrm{N}_{2}$ fixation (Adeli et al. 2005). Thus, poultry litter's use as a soil amendment in soybean production, in particular specialty soybean production, has not been extensively documented. A few studies have reported the potential benefits of poultry litter fertilization for increasing soybean yield (Adeli et al. 2005; Slaton et al. 2009; Watts and Torbert 2011), but a research gap exists on other crop and seed quality components (e.g., taste, sweetness, texture, and nutrient content), which are of particular importance for value-added crops such as vegetable soybean, edamame, and that are affected by environmental factors and agronomic conditions.

Poultry litter can be applied to soil in different forms (e.g., fresh, composted, pelletized) with varying chemical composition and properties. Composting can be beneficial for pathogen reduction, nutrient stabilization, and the slow release of nutrients to soil that may increase organic matter and improve nutrient retention, reducing detrimental environmental effects associated with nutrient buildup and subsequent losses (Preusch et al. 2002). While both composted and pelletized forms may provide easier alternatives for handling of poultry manure than the fresh form, pelletized poultry litter may offer greater feasibility for transportation and handling due to its lower moisture content relative to composted. Because of the high temperatures and pressure used in the pelleting process, pelletized litters may have greater particle size and nutrient uniformity than composted litter (Hadas et al. 1983), less odor, and may increase $\mathrm{N}$ mineralization rates (Hadas et al. 1983; Golden et al. 2006; Wild et al. 2011). However, little is known about the properties of formulated pelletized litter and its effects on soil and crop parameters.

As a part of sustainable farming practices, applications of poultry litter to soils with low organic matter can provide substrate for microorganisms, promoting microbial biomass and fueling biological activity and nutrient mineralization rates (e.g., Gunapala et al. 1998). Since organic amendments can improve soil quality and promote nutrient cycling, organic nutrient sources such as poultry litter may provide some of the growth and development requirements of soybean and promote sustainable practices that reduce the buildup of soil nutrients to deleterious levels (Singer and Heckman 2003).
Greenhouse and field studies were conducted at the University of Arkansas Agriculture and Extension Center in Fayetteville, Arkansas (Fig. 1), to investigate soil and crop quality at different growth stages resulting from land application of composted and formulated pelletized (hereafter referred to simply as formulated) poultry litter as an organic carbon $(\mathrm{C})$ and $\mathrm{P}$ nutrient source for edamame production in Arkansas. We hypothesized that, if composted or formulated poultry litter had measurable effects on soil properties, those would improve plant nutrient uptake and edamame seed quality.

\section{Materials and methods}

Greenhouse and field experiments were conducted in 2005 in a Captina silt loam soil (fine-silty, mixed, mesic Typic Fragiudult). The soil used for the greenhouse experiment was collected from the location where the field trials were to be conducted. Soil test results analyzed prior to fertilization indicated a $\mathrm{pH}$ of 6.2 (1:2 soil to water wt:vol ratio), $1.08 \%$ total C, $0.1 \%$ total $\mathrm{N}$ (high-temperature combustion, LECO, St. Joseph, MI), and Mehlich-3 P (Mehlich 1984) of $230 \mathrm{~kg} \mathrm{P} \mathrm{ha}^{-1}$ extracted at a 1:10 soil to extract (wt:vol) ratio and measured by inductively coupled plasma spectroscopy (SPECTRO CIROS ICP, Fitchburg, MA). The edamame soybean breeding line R01-3567 (maturity group V) from the University of Arkansas was used. A no-addition control, a non-labeled composted litter, and a formulated poultry litter labeled 4-6-4 (formulated 4-6-4) were used in the greenhouse and field studies. In the field, a second formulated litter labeled 4-2-2 (formulated 4-2-2) was also incorporated as a treatment. Each litter was applied at a rate of $112 \mathrm{~kg} \mathrm{P} \mathrm{ha}^{-1}$ (Table 1). The composted litter was collected from Peterson Farms in Decatur, Arkansas, and the formulated litters were provided by Lee Harris Farms in Cave Springs, Arkansas.

In the greenhouse, for each pot, the total amount of soil $(6.6 \mathrm{~kg})$ was mixed in steel bowls with the total amount of fertilizer (21 g composted, $20 \mathrm{~g}$ formulated 4-6-4), calculated on a dry weight basis. Pots were filled and packed to a final volume of $6,570 \mathrm{~cm}^{3}$ and bulk density of $1.0 \mathrm{~g} \mathrm{~cm}^{-3}$. Each pot served as an experimental unit, and each treatment included 16 replications per treatment. Pots were arranged in a completely randomized experimental design in the greenhouse. Three seeds inoculated with Bradyrhizobium sp. were planted in each pot and subsequently thinned to one plant per pot after emergence. Pots were placed on individual $30.5 \mathrm{~cm}$ diameter liners and watered from below as needed until reproductive stage 6 , full pod-R6.

Field plots for each treatment were four rows wide (1-m row spacing) and $10.7 \mathrm{~m}$ long, established in a randomized complete block design with three replications. Uncultivated alleys, $4.6 \mathrm{~m}$ wide and running the length of the field, served 

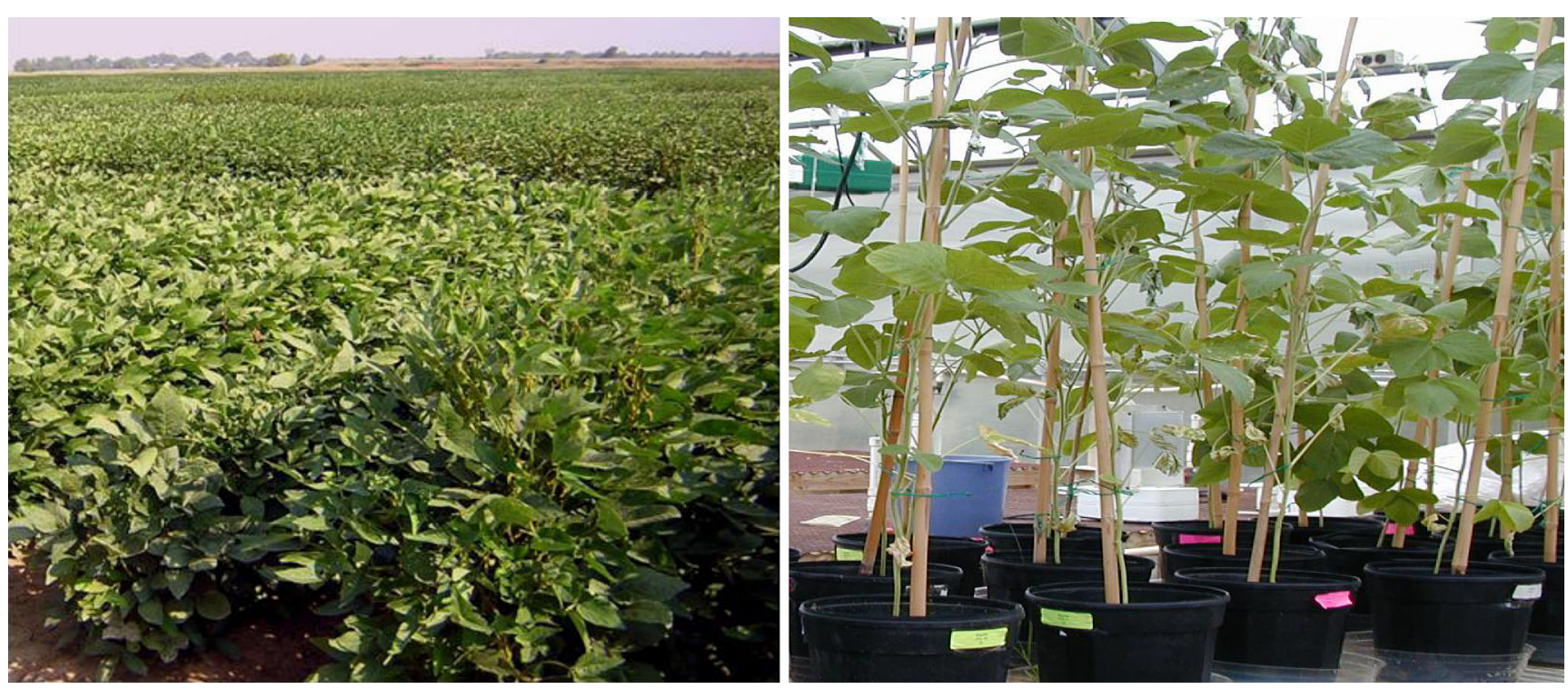

Fig. 1 Field study (left) and greenhouse study (right) investigating the effects of composted and formulated poultry litter amendments on soil quality and edamame soybean production conducted at the University of Arkansas Agriculture and Extension Center in Fayetteville, Arkansas

as buffer zones between treatments. Litters were spread by hand and incorporated through disking to a depth of $10 \mathrm{~cm}$. Seeds were planted a day after litter application at a density of 30 seeds per meter. Irrigation was done with the use of a traveling gun using the University of Arkansas Irrigation Scheduler and stopped after the full pod-R6 stage.

Soil samples from the greenhouse and field experiments were collected at four stages: time 0 (after litter incorporation to soil, prior to planting), vegetative stage 5 or fifth node-V5, reproductive stage 1 or first flower-R1, and reproductive stage 6 or full pod-R6. In the greenhouse, four randomly selected pots were sampled destructively for soil analyses at each stage. The soil from each pot was mixed in aluminum tins, and a representative soil sample was collected. In the field, composite soil samples were collected from eight random points in each plot to a depth of $10 \mathrm{~cm}$ using a stainless steel probe.

Greenhouse and field soil samples were analyzed for Mehlich-3 extractable P (time 0 and full pod-R6 only), water soluble $\mathrm{P}$, and alkaline phosphatase activities. Field samples were also analyzed for dissolved organic $\mathrm{C}$, inorganic $\mathrm{N}$, and $\beta$-glucosaminidase activities. A TOC analyzer (Shimadzu, Inc., Columbia, MD) was used to measure dissolved organic $\mathrm{C}$ in soil extracted at a $1: 2$ soil:0.5 $\mathrm{M} \mathrm{K}_{2} \mathrm{SO}_{4}$ (wt:vol) ratio (Jones and Willett 2006). Inorganic N (1:10 soil:2M KCl (wt:vol) ratio) and water soluble P (1:10 soil to water (wt:vol) ratio) were measured colorimetrically on a nutrient autoanalyzer (Skalar, Inc., Norcross, GA) using the methods of Bundy and Meisinger (1994) and Kuo (1994), respectively. Mehlich-3 extractable P was analyzed on filtered extracts (1:10 soil to solution (wt:vol) ratio) by the method of Mehlich (1984) using inductively coupled plasma spectroscopy (SPECTRO CIROS ICP, Fitchburg, MA). Enzyme activities were determined spectrophotometrically by the production of $p$-nitrophenol following hydrolysis of a substrate (Tabatabai 1994; Parham and Deng 2000).

In the greenhouse, green pods were collected from all pots in each treatment at the full pod-R6 stage for determination of pod count and weight. In the field, plant tissue samples were obtained from whole plants at the reproductive stages in the

Table 1 Nutrient content of the composted poultry litter and two formulated poultry litters labeled 4-6-4 and 4-2-2 used in the greenhouse and field experiments, based on a $\mathrm{P}$ application rate of $112 \mathrm{~kg} \mathrm{ha}^{-1}$

\begin{tabular}{|c|c|c|c|c|c|c|}
\hline \multirow[t]{2}{*}{ Experiment } & \multirow[t]{2}{*}{ Poultry litter type } & \multicolumn{2}{|c|}{ Nutrient content ratio $\left(\mathrm{N}-\mathrm{P}_{2} \mathrm{O}_{5}-\mathrm{K}_{2} \mathrm{O}\right)$} & \multicolumn{3}{|c|}{ Amounts added $\left(\mathrm{kg} \mathrm{ha}^{-1}\right)$} \\
\hline & & Labeled & Measured Equivalent & Fertilizer & $\mathrm{N}$ & $\mathrm{C}$ \\
\hline Greenhouse and field & Composted & N/A & $1.8-4.5-1.3$ & $5,744.3$ & 100.5 & $1,514.2$ \\
\hline Greenhouse and field & Formulated 4-6-4 & $4-6-4$ & $4.7-4.7-4.0$ & $5,437.6$ & 253.4 & $1,903.7$ \\
\hline Field only & Formulated 4-2-2 & $4-2-2$ & $5.0-5.1-4.0$ & $5,000.6$ & 249.0 & $1,759.2$ \\
\hline
\end{tabular}

All weights were calculated on a dry weight basis. For formulated litters, the amount of litter added was based on the measured $\mathrm{P}_{2} \mathrm{O}_{5}$ content. The composted litter was collected from Peterson Farms in Decatur, AR, and the formulated litters were provided by Lee Harris Farms in Cave Springs, Arkansas; N/A = data not available 
field from all plants collected within $1 \mathrm{~m}$ long sections in the two middle rows in each plot. Plant tissue $\mathrm{N}$ and $\mathrm{P}$ concentrations were measured by inductively coupled plasma spectroscopy (SPECTRO CIROS ICP, Fitchburg, MA) following acid digestion using method 3050B (USEPA 1996). Plants were grown to full maturity (reproductive stage 8 , full maturity-R8) in the field for analyses of seed size (number of seeds per pound) and composition (protein, oil, fiber, and sucrose contents). Seed protein and oil concentrations were measured with a grain analyzer (FOSS NIRSystems, Inc, Laurel, MD) by assessing near infrared transmittance. Crude fiber was determined by the American Oil Chemists' Association (AOCS)-approved filter bag technique (ANKOM technology, Macedon, NY), and sucrose was analyzed using high performance liquid chromatography (Dionex, Sunnyvale, CA).

Analysis of variance (ANOVA) was performed using the Proc GLM procedure in SAS (SAS Institute, Cary, NC) to determine significant differences in soil and plant variables among treatments within each sampling stage. Greenhouse and field studies ( $n=4$ and $n=3$ per sampling stage, respectively, unless otherwise specified) were analyzed separately. Least significant difference (LSD) and a critical value of $p<0.05$ were used for means separation and comparisons.

\section{Results and discussion}

\subsection{Phosphorus}

Application of composted and formulated poultry litters increased Mehlich-3 and water soluble P. In the greenhouse, Mehlich-3 P concentrations were significantly higher in soil amended with composted litter and formulated litters compared to the control at time 0 and the full pod-R6 stage, but no differences were observed between the different types of litters (Table 2). In contrast to the greenhouse, no differences were observed in Mehlich-3 $\mathrm{P}$ concentrations at time 0 in the field (Table 3). Higher concentrations were measured in the formulated 4-6-4 treatments in the field compared to both the control and composted litter treated soil at the full pod-R6 stage, but formulated 4-2-2 litter was not significantly different than the control or other litter treatments, and composted litter did not differ from the control.

Mehlich-3 extracts have been studied in fertility experiments in the southeastern USA to correlate plant responses to fertilizer additions, but not all $\mathrm{P}$ extracted with Mehlich-3 is water soluble. Water soluble P increased from composted and formulated poultry litters, ranging from a $33 \%$ increase in formulated 4-6-4 soil in the greenhouse (Table 2) to a $316 \%$ increase in formulated 4-2-2 soil in the field (Table 3), both at the fifth node-V5 stage. Water soluble P concentrations depended on plant growth stage, management, and poultry litter. Water soluble $\mathrm{P}$ concentrations were higher than the control at all stages in the composted litter and at the first flower-R1 stage in formulated 4-6-4 litter treatment in the greenhouse (Table 2). Field soil concentrations of water soluble $\mathrm{P}$ were higher in the composted litter treatment compared to the control at the fifth node-V5 stage (Table 3). In addition, significantly higher water soluble $\mathrm{P}$ concentrations were observed in formulated 4-2-2 treated soil at the fifth node-V5 stage compared to the formulated 4-6-4 treatment and at both reproductive stages compared to all other treatments.

The increased $\mathrm{P}$ concentrations are consistent with results from a previous study using poultry manure in soybean (Adeli et al. 2005) and were expected because all litters were added for $\mathrm{P}$ fertilization. Although the two formulated litters were selected initially for comparison based on their different $\mathrm{P}$ content as labeled, pre-plant analysis indicated that the nutrient content was different to the manufacturers' specifications, and both litters had similar N-P-K contents. Composted litter had less than half the $\mathrm{N}$ and $\mathrm{K}$ content of the formulated litters but similar $\mathrm{P}$ composition. Even though all fertilizers had a similar P content, differences in soil P concentrations were observed among treatments, and soil responses to application of the two formulated

Table 2 Mean water soluble phosphorus (P), Mehlich-3 extractable P, and alkaline phosphatase activities in soil measured at different plant growth stages in the no-addition control and litter-treated pots in the greenhouse experiment

\begin{tabular}{|c|c|c|c|c|c|c|c|c|c|c|}
\hline \multirow[t]{2}{*}{ Poultry litter treatment } & \multicolumn{4}{|c|}{$\begin{array}{l}\text { Water soluble } \mathrm{P} \\
\left(\mu \mathrm{g} \mathrm{P} \text { g dry soil }{ }^{-1}\right)\end{array}$} & \multicolumn{2}{|c|}{$\begin{array}{l}\text { Mehlich-3 P } \\
\left(\mu \mathrm{g} \text { P g dry soil }{ }^{-1}\right)\end{array}$} & \multicolumn{4}{|c|}{$\begin{array}{l}\text { Alkaline phosphatase } \\
\left(\mu \mathrm{g} p \text {-nitrophenol } \mathrm{g}^{-1} \mathrm{~h}^{-1}\right)\end{array}$} \\
\hline & $\mathrm{T} 0$ & V5 & $\mathrm{R} 1$ & R6 & $\mathrm{T} 0$ & R6 & T0 & V5 & $\mathrm{R} 1$ & R6 \\
\hline Control & 6.4 & 8.0 & 6.0 & N/A & 94 & 153 & 48.9 & 49.6 & 20.2 & 25.0 \\
\hline Composted, non-labeled & 13.9 & 12.2 & 10.6 & N/A & 119 & 187 & 36.5 & 53.4 & 48.3 & 13.5 \\
\hline Formulated, labeled 4-6-4 & 10.7 & 10.7 & 11.2 & N/A & 117 & 177 & 61.7 & 63.9 & 33.7 & 36.0 \\
\hline LSD & 4.8 & 3.5 & 4.4 & N/A & 10 & 17 & 27.2 & 19.5 & 15.2 & 16.4 \\
\hline
\end{tabular}

Two different poultry litter treatments were applied at rates equivalent to $112 \mathrm{~kg} \mathrm{P} \mathrm{ha}^{-1}$ and parameters were measured at time 0 (T0; after litter incorporation to soil, prior to planting), vegetative stage 5 (fifth node, V5), reproductive stage 1 (first flower, R1), and reproductive stage 6 (full pod, R6). Least significant difference (LSD) and a critical value of $p<0.05$ were used for means separation ( $n=4$ for water soluble $\mathrm{P}$ and alkaline phosphatase; $n=3$ for Mehlich-3 P). N/A = data not available 
Table 3 Mean water soluble phosphorus (P), Mehlich-3 extractable $\mathrm{P}$, and alkaline phosphatase activities in soil plots measured at different plant growth stages in the no-addition control and litter-treated field

\begin{tabular}{|c|c|c|c|c|c|c|c|c|c|c|}
\hline \multirow[t]{2}{*}{ Poultry litter treatment } & \multicolumn{4}{|c|}{$\begin{array}{l}\text { Water soluble } \mathrm{P} \\
\left(\mu \mathrm{g} \mathrm{P} \text { g dry soil }{ }^{-1}\right)\end{array}$} & \multicolumn{2}{|c|}{$\begin{array}{l}\text { Mehlich-3 P } \\
\left(\mu \mathrm{g} \text { P g dry soil }{ }^{-1}\right)\end{array}$} & \multicolumn{4}{|c|}{$\begin{array}{l}\text { Alkaline phosphatase } \\
\left(\mu \mathrm{g} p \text {-nitrophenol } \mathrm{g}^{-1} \mathrm{~h}^{-1}\right)\end{array}$} \\
\hline & T0 & V5 & $\mathrm{R} 1$ & R6 & T0 & R6 & T0 & V5 & $\mathrm{R} 1$ & R6 \\
\hline Control & 6.2 & 7.4 & 7.5 & 7.7 & 113 & 173 & 18.6 & 23.6 & 9.9 & 42.1 \\
\hline Composted, non-labeled & 17.4 & 30.3 & 11.4 & 10.9 & 112 & 168 & 72.7 & 63.2 & 17.0 & 25.6 \\
\hline Formulated, labeled 4-6-4 & 10.1 & 12.6 & 10.9 & 12.2 & 126 & 253 & 81.3 & 47.7 & 8.0 & 33.3 \\
\hline Formulated, labeled 4-2-2 & 12.8 & 31.0 & 21.3 & 19.6 & 113 & 231 & 79.1 & 94.5 & 14.2 & 40.2 \\
\hline LSD & 12.8 & 9.6 & 6.5 & 5.3 & 21 & 67 & 24.6 & 60.7 & 12.5 & 20.9 \\
\hline
\end{tabular}

Three different poultry litter treatments were applied at rates of $112 \mathrm{~kg} \mathrm{P} \mathrm{ha}^{-1}$ and parameters were measured at time 0 ( $\mathrm{T} 0$; after litter incorporation to soil, prior to planting), vegetative stage 5 (fifth node, V5), reproductive stage 1 (first flower, R1), and reproductive stage 6 (full pod, R6). Least significant difference (LSD) and a critical value of $p<0.05$ were used for means separation $(n=3)$

litters were different throughout the growing season. The lack of congruence in responses observed in P concentrations in soil receiving formulated litters compared to composted litter, and between the two formulated litters, emphasizes that similar organic amendments (poultry litters) may promote different biochemical reactions in amended soil, making it difficult to predict nutrient release from treated litters based on $\mathrm{P}$ content alone.

Because phosphate will be mineralized from organic compounds through the activities of enzymes, alkaline phosphatase activities were measured. Differences in alkaline phosphatase activities in the greenhouse were observed at the reproductive stages, where higher enzyme activities were observed in composted litter-amended soil at the first flower-R1 stage compared to the control and in formulated 4-6-4-amended soil at the full pod-R6 stage compared to the composted treatment (Table 2). In the greenhouse, except for the formulated 4-6-4 litter treated soil at time 0 , all soil $\mathrm{pH}$ values were similar, ranging from 5.1 to 5.4 (data not shown, Blair 2007). In the field, measurable differences in alkaline phosphatase activities were observed at time 0 and the vegetative stage but not during the reproductive period. At time 0 , higher activities were measured in all litter-amended soils than in the control (Table 3). At the fifth node-V5 stage, only formulated 4-2-2 had higher alkaline phosphatase activity than the control, and no differences were measured among litter types at any stage in the field. Alkaline phosphatase is expected to be positively related to increased $\mathrm{pH}$ (Deng and Tabatabai 1997). In the field, $\mathrm{pH}$ was similar to the greenhouse, ranging from 5.0 to 5.7 in all plots (data not shown, Blair 2007), indicating that differences in alkaline phosphatase activities were likely a result of changes induced by poultry litter application but were not directly related to $\mathrm{pH}$.

Poultry litter application induced changes in the activities of enzymes involved in P cycling, indicating a stimulation of microbial enzyme activities that provide a biochemical mechanism of release of phosphate from organic forms in poultry litter and soil organic matter, consistent to that reported in previous studies (e.g., Acosta-Martinez and Harmel 2006).
While changes in enzyme activities are expected because microbial activities are sensitive indicators of changes in soil quality (Gunapala et al. 1998; Acosta-Martinez and Harmel 2006), and because they tend to be correlated with additions of dissolved organic C (Deng and Tabatabai 1997), the increase in alkaline phosphatase activities is interesting because phosphatase activities tend to be inhibited by the presence of high available $\mathrm{P}$ concentrations in soil. Alkaline phosphatase activities are indicative of the recycling of $\mathrm{P}$ from poultry litter and may have contributed partially to an increase in soluble $\mathrm{P}$ concentrations.

\subsection{Carbon and nitrogen}

Organic substrate for soil microorganisms added with poultry litter application is evidenced by increased dissolved organic $\mathrm{C}$ concentrations which were higher in formulated 4-2-2 field plots compared to composted and control soil at time 0 and compared to the control and all treatments at all sampling stages after time 0 (Table 4). Addition of organic substrates fuels enzyme activities such as $\beta$-glucosaminidase activity involved in $\mathrm{C}$ and $\mathrm{N}$ cycling. An initial increase in the activities of $\beta$-glucosaminidase was observed in the field following addition of formulated 4-6-4 litter which was higher than in the control (Table 4). Additionally, field plots amended with both formulated litters had significantly higher activities than the control at the fifth node-V5 and reproductive stages. Furthermore, $\beta$-glucosaminidase activities in formulated 42-2-amended soil in the field was higher than that measured in composted litter treatment at the fifth node-V5 and reproductive stages, while in formulated 4-6-4 litter plots, $\beta$ glucosaminidase activities were significantly higher than in composted litter plots only at the full pod-R6 stage. The increases in $\beta$-glucosaminidase activities in the formulated treatments in the field at the vegetative and reproductive stages were consistent with those reported by AcostaMartinez and Harmel (2006). While $\beta$-glucosaminidases 
Table 4 Mean dissolved organic carbon $(\mathrm{C})$, inorganic nitrogen $(\mathrm{N})$, and $\beta$-glucosaminidase activities in soil measured at different plant growth stages in the no-addition control and litter-treated field

\begin{tabular}{|c|c|c|c|c|c|c|c|c|c|c|c|c|}
\hline \multirow[t]{2}{*}{ Poultry litter treatment } & \multicolumn{4}{|c|}{$\begin{array}{l}\text { Dissolved organic C } \\
\left(\mu \mathrm{g} \mathrm{C} \text { g dry soil }{ }^{-1}\right)\end{array}$} & \multicolumn{4}{|c|}{$\begin{array}{l}\text { Inorganic N } \\
\left(\mu \mathrm{g} \mathrm{N} \mathrm{g} \mathrm{dry} \mathrm{soil}{ }^{-1}\right)\end{array}$} & \multicolumn{4}{|c|}{$\begin{array}{l}\beta \text {-glucosaminidase } \\
\left(\mu \mathrm{g} p \text {-nitrophenol } \mathrm{g}^{-1} \mathrm{~h}^{-1}\right)\end{array}$} \\
\hline & T0 & V5 & $\mathrm{R} 1$ & R6 & T0 & V5 & $\mathrm{R} 1$ & R6 & T0 & V5 & $\mathrm{R} 1$ & R6 \\
\hline Control & 25.9 & 33.0 & 49.7 & 48.5 & 18.3 & 39.4 & 29.6 & 6.9 & 21.2 & 20.4 & 32.6 & 27.1 \\
\hline Composted, non-labeled & 40.5 & 48.5 & 64.9 & 63.4 & 24.0 & 52.8 & 22.1 & 13.4 & 30.6 & 22.1 & 41.1 & 29.9 \\
\hline Formulated, labeled 4-6-4 & 55.7 & 41.4 & 59.2 & 64.1 & 35.6 & 113.7 & 94.4 & 47.2 & 32.3 & 26.3 & 46.2 & 56.2 \\
\hline Formulated, labeled 4-2-2 & 92.8 & 69.9 & 87.5 & 86.4 & 64.8 & 182.6 & 147.9 & 74.3 & 30.4 & 39.0 & 54.5 & 45.2 \\
\hline LSD & 49.7 & 18.2 & 17.3 & 21.3 & 19.3 & 41.0 & 76.8 & 81.2 & 9.6 & 5.1 & 7.8 & 10.3 \\
\hline
\end{tabular}

Three different poultry litter treatments were applied at rates of $112 \mathrm{~kg} \mathrm{P} \mathrm{ha}^{-1}$, and parameters were measured at time 0 (T0; after litter incorporation to soil, prior to planting), vegetative stage 5 (fifth node, V5), reproductive stage 1 (first flower, R1), and reproductive stage 6 (full pod, R6). Least significant difference (LSD) test and a critical value of $p<0.05$ were used for means separation $(n=3)$

contribute to decomposition and may promote soil quality, activities of these enzymes also may likely lead to further release of $\mathrm{N}$ from poultry litter to soil, particularly from formulated litters since composted litters would be expected to have stabilized organic matter from the composting process (Preusch et al. 2002).

Concentrations of inorganic $\mathrm{N}$ measured in the field soil treated with formulated litters (formulated 4-2-2 at time 0, both formulated litters at the fifth node-V5 stage, and formulated 4-2-2 at the first flower-R1 stage) were higher than in the composted litter and in the control (Table 4). Formulated 4-22 -amended plots had significantly higher concentrations than formulated 4-6-4-amended plots at time 0 and the fifth nodeV5 stage (Table 4). Soil treated with composted litter did not significantly differ from the control in inorganic $\mathrm{N}$ at any stage in this study. It has been suggested that the processes involved in the pelleting of formulated litters can promote $\mathrm{N}$ mineralization in soil (Hadas et al. 1983; Wild et al. 2011), which could help explain the increases in $\mathrm{N}$ availability shortly after incorporation of formulated litters into soil.

\subsection{Plant nutrient uptake and seed composition}

Poultry litter can be an important source of several nutrients essential for plant growth that are removed from soils during plant uptake and harvest (Sharpley et al. 2004); however, if mineralized and released nutrients are not taken up by growing plants, the increase in availability can become an environmental pollution problem. In our study, despite the differences in available $\mathrm{N}$ and $\mathrm{P}$ in soil during plant growth, poultry litter application did not affect plant tissue concentrations of these nutrients at the reproductive stages. Plant tissue $\mathrm{N}$ concentrations for the control, composted, formulated 4-6-4, and formulated 4-2-2 poultry litters, respectively, were 5.6, 5.2, 5.5, and $5.5 \mu \mathrm{g} \mathrm{N} \mathrm{g}^{-1}$ at the first flower-R1 stage and 4.3, 4.4, 4.1, and $4.2 \mu \mathrm{g} \mathrm{N} \mathrm{g}^{-1}$ at the full pod-R6 stage. Plant tissue $\mathrm{P}$ concentrations in the control, composted, formulated 4-6-4, and formulated 4-2-2- poultry litters, respectively, were 0.3 , $0.3,0.3$, and $0.4 \mu \mathrm{g} \mathrm{P} \mathrm{g}^{-1}$ at the first flower-R1 stage, and 0.2, $0.3,0.3$, and $0.2 \mu \mathrm{g} \mathrm{P} \mathrm{g}^{-1}$ at the full pod-R6 stage.

These results are contrary to those of Slaton et al. (2009) who detected differences in trifoliate leaf $\mathrm{P}$ concentrations in non-fertilized compared to poultry-amended plants in soil with optimum soil test $\mathrm{P}$ level receiving an application rate of approximately $160 \mathrm{~kg} \mathrm{P} \mathrm{ha}{ }^{-1}$. The lack of differences in plant $\mathrm{P}$ uptake in this study could have resulted from a higher background soil $\mathrm{P}$ concentration or from inappropriate timing of poultry litter application. It is suggested that $\mathrm{P}$ should be applied near planting to maximize plant uptake and reduce $\mathrm{P}$ retention in soil in less available forms (Snyder et al. 2001), but Slaton et al. (2009) suggests that a timing of application of several months before planting should also be evaluated. In our study, similar plant tissue P concentrations among treatments and the control may indicate that the release of available $\mathrm{P}$ to soil was not coincidental with plant uptake, of which $60 \%$ occurs after reproductive stage 2 (full bloom-R2) (Snyder et al. 2001). This highlights the importance of conducting further studies to determine optimum rates and timing of litter application so as to maximize plant $\mathrm{P}$ uptake and minimize nutrient buildup in soils and subsequent losses.

In addition to plant nutrient concentrations, crop quality was assessed using pod yield and seed components that are of particular importance to edamame. Average pod count and pod weights were statistically similar across all treatments in the greenhouse with averages of 34,31 , and 28 pods per plant and $62.7,46.9$, and $46.5 \mathrm{~g}$ per plant in the control, composted, and formulated 4-6-4 litter treatments, respectively ( $p>0.05$; data not shown; Blair 2007). In the field, seed size in plants in the control and composted treatment (4,480 and 4,793 seeds $\mathrm{kg}^{-1}$, respectively) was slightly larger than seed size in plants amended with formulated litter (3,896 and 4,311 seeds $\mathrm{kg}^{-1}$ in formulated 4-2-2 and 4-6-4, respectively).

In our study, seed composition attributes were evaluated using dry seed harvested at the full maturity-R8 stage instead 
of using immature seed collected at the full pod-R6 stage. Seed composition results in the composted litter treatment were comparable to those of the control and, except for crude fiber and oil contents, seed components were also not impacted by formulated poultry litter application. Crude fiber in edamame seed was lower in content in formulated 4-6-4 than all other treatments including the control, while addition of both formulated litters slightly decreased seed oil content with values of $22.3 \%$ in the control and 22.2, 21.5 and $21.8 \%$ in composted, formulated 4-6-4, and formulated 4-2-2 treatments (data not shown; Blair 2007). Average seed protein ranged from 41.7 to $42.6 \%$ and average sucrose content ranged from 26.2 to $28.6 \mathrm{mg} \mathrm{g}^{-1}$ in the control and treated plots (data not shown; Blair 2007). Despite significant differences observed in fiber and oil content, overall seed composition values remained typical for Arkansas soybean (e.g., $20 \%$ oil and $40 \%$ protein; Ashlock et al. 2001). Mozzoni (2009) observed positive correlations in protein and sucrose contents between the full pod-R6 and full maturity-R8 stages in vegetable soybean. Thus, the results observed at the full maturity-R8 stage can be used as indicators of seed quality at the full pod-R6 stage while helping to overcome some of the challenges of working with immature seed.

Overall, because dissolved organic $\mathrm{C}$, inorganic $\mathrm{N}$ results, and $\beta$-glucosaminidase activities indicated that composted poultry litter was a more stable form of organic substrate, it may be a better alternative than formulated litter for application to soil in edamame production. However, release of $\mathrm{P}$ may limit the use of composted poultry litter in high P soils, especially if use is not coupled with plant $\mathrm{P}$ uptake because organic amendments stimulate enzymatic activities, including alkaline phosphatases that contribute to further release of $P$. Thus, we recommend that application rate for edamame be kept low (e.g., less than $112 \mathrm{~kg} \mathrm{P} \mathrm{ha}^{-1}$ ), especially in soil with higher P levels.

\section{Conclusion}

Short-term soil enzyme and nutrient and crop quality responses of an edamame crop to pre-plant application of composted or formulated pelletized poultry litter were evaluated in greenhouse and field experiments. It was hypothesized that addition of organic fertilizer, in this case poultry litter, would benefit crop quality by increasing soil enzyme activities and improve nutrient cycling, availability, and plant uptake, which would meet performance criteria for value-added edamame. Poultry litter immediately altered enzyme activities and $\mathrm{C}, \mathrm{N}$, and $\mathrm{P}$ concentrations in soil, with magnitude depending on greenhouse and field conditions, plant growth stage, and composted or formulation treatment of poultry litter. Contrary to our hypothesis, plant and seed quality parameters were similar between unfertilized and poultry litter fertilized edamame plants. Results of nutrient added formulations even though added to soil at the same $\mathrm{P}$ application rate were not consistent among poultry litters and emphasized the challenges for agronomists and farmers in understanding release of nutrients in soil. Because composted poultry litter resulted in the least excess inorganic $\mathrm{N}$ without any reduction in crop quality, it may be a better organic soil amendment for edamame production than formulated poultry litters. However, increased alkaline phosphatase activities and soluble $\mathrm{P}$ concentrations may limit rates of composted poultry litter.

Acknowledgments We thank Dr. Nathan Slaton for his guidance, Dr. Ed Gbur for assistance with statistical analysis, and the technical assistance of the Soil Biology and Microbial Ecology and Soybean Breeding groups, with special thanks to Tatsuya Akiyama, Caroline Grey, Tetsuaki Ishibashi, Juan Mayta, Leandro Mozzoni, and Peter Tomlinson. We are grateful to Mr. Lee Harris from Lee Harris Farms and Peterson Farms in Decatur, Arkansas for providing the poultry litters. This work was funded with assistance from the University of Arkansas Division of Agriculture.

\section{References}

Acosta-Martínez V, Harmel RD (2006) Soil microbial communities and enzyme activities under various poultry litter application rates. J Environ Qual 35:1309-1318. doi:10.2134/jeq2005.0470

Adeli A, Sistani KR, Rowe DE, Tewolde H (2005) Effects of broiler on soybean production and soil nitrogen and phosphorus concentrations. Agron J 97:314-321. doi:10.2134/agronj2005.0314

Arkansas Soybean Promotion Board (2011) Arkansas ag statistics. http:// www.arspb.org/statistics/index.html. Accessed 06 December 2013

Ashlock L, Longer D, Smith M (2001) Chapter 4: Seed grain composition, quality and testing. In: Arkansas Soybean Handbook. University of Arkansas Cooperative Extension Service Publication MP 197, pp 17-20

Blair R (2007) Soil and plant quality of a vegetable soybean crop following application of different types of poultry litter. MSc thesis, University of Arkansas

Bundy LG, Meisinger JJ (1994) Nitrogen availability indices. In: Bigham JM (ed) methods of soil analysis, part 2. Microbiological and biochemical properties. Chemical Methods. ASA, SSSA, Madison, WI, pp 951-984

Deng SP, Tabatabai MA (1997) Effect of tillage and residue management on enzyme activities in soils: III phosphatases and arylsulfatase. Biol Fertil Soils 24:141-146. doi:10.1007/s003740050222

Espinoza L, Slaton N, Mozaffari M, Daniels M (2007) The use of poultry litter in row crops. University of Arkansas Cooperative Extension Service sheet FSA-2147

Golden BR, Slaton NA, Norman RJ, Gbur EE Jr, Brye KR, DeLong RE (2006) Recovery of nitrogen in fresh and pelletized poultry litter by rice. Soil Sci Soc Am J 70:1359-1369. doi:10.2136/sssaj2005.0298

Gunapala N, Venette RC, Ferris H, Scow KM (1998) Effects of soil management history on the rate of organic matter decomposition. Soil Biol Biochem 30:1917-1927. doi:10.1016/S0038-0717(98) 00062-5

Hadas A, Bar-Yosef B, Davidov S, Sofer M (1983) Effect of pelleting, temperature, and soil type on mineral nitrogen release from poultry and dairy manure. Soil Sci Soc Am J 47:1129-1133. doi:10.2136/ sssaj 1983.03615995004700060014x

Jones DL, Willett VB (2006) Experimental evaluation of methods to quantify dissolved organic nitrogen $(\mathrm{DON})$ and dissolved organic 
carbon (DOC) in soil. Soil Biol Biochem 38:991-999. doi:10.1016/ j.soilbio.2005.08.012

Kuo S (1994) Phosphorus. In: Bigham JM (ed) Methods of soil analysis, Part 3. Chemical Methods. ASA, SSSA, Madison, WI, pp 869-920

Mehlich A (1984) Mehlich-3 soil test extractant: a modification of Mehlich-2 extractant. Commun Soil Sci Plant Anal 15:1409-1416. doi: $10.1080 / 00103628409367568$

Mozzoni L (2009) Quality attributes, processing, and selection of vegetable soybean. $\mathrm{PhD}$ dissertation, University of Arkansas

Nass HG, Ivany JA, MacLeod LA (2003) Agronomic performance and quality of spring wheat and soybean cultivars under organic agriculture. Am J Alternat Agric 18:164-170. doi:10.1079/AJAA200348

Parham JA, Deng SP (2000) Detection, quantification and characterization of $\beta$-glucosaminidase activity in soil. Soil Biol Biochem 32: 1183-1190. doi:10.1016/S0038-0717(00)00034-1

Pederson GA, Brink GE, Fairbrother TE (2002) Nutrient uptake in plant parts of sixteen forages fertilized with poultry litter: Nitrogen, phosphorus, potassium, copper, and zinc. Agron J 94:895-904. doi:10. 2134/agronj2002.8950

Preusch PL, Adler P, Sikora LJ, Tworkoski TJ (2002) Nitrogen and phosphorus availability in composted and uncomposted poultry litter. J Environ Qual 31:2051-2057. doi:10.2134/jeq2002.2051

Sharpley AN, McDowell RW, Kleinman PJA (2004) Amounts, forms, and solubility of phosphorus in soils receiving manure. Soil Sci Soc Am J 68:2048-2057. doi:10.2136/sssaj2004.2048

Singer JW, Heckman JR (2003) Soybean response to plant density and residual soil management. J Sustain Agron 23:79-90. doi:10.1300/ J064v23n02 07

Slaton N, Delong R, Branson J, Clark S, Mozaffari M, Norman RJ, Schaeffer J, Thompson R, Snyder C (2003) Soybean response to phosphorus and potassium fertilization. Potash and Phosphate Institute (PPI). http://www.ipni.net/far/farguide.nsf/\$webindex/ article $=8$ F99377386257018005F6347FF3FB71E?opendocument. Accessed 06 December 2006
Slaton NA, Delong RE, Mozaffari M, Shafer J, Golden B, Maschmann E, Branson J (2009) Soybean response to phosphorus and potassium fertilization. In: Slaton NA (ed) Wayne E, vol 569, Sabbe Arkansas Soil Fertility Studies 2008. AAES Research Series., pp 51-56

Snyder C, Sabbe W, Chapman S, Daniels M (2001) Chapter 5: fertilization and liming practices. In: Arkansas soybean handbook. University of Arkansas Cooperative Extension Service Publication MP 197, pp 2-26

Tabatabai MA (1994) Soil enzymes. In: Doran JW, Jones AJ (ed) methods of soil analysis, part 2. Microbiological and biochemical properties. SSSA Special Publication Number 49. ASA, SSSA, Madison, WI, pp 775-833

United States Department of Agriculture-National Agriculture Statistics Service (USDA-NASS) (2012) Poultry - Production and Value 2011 Summary, April 2012. http://usda01.library.cornell.edu/usda/nass/ PoulProdVa//2010s/2012/PoulProdVa-04-26-2012.pdf. Accessed 06 December 2013

United States Environmental Protection Agency (USEPA) (1996) Test methods for evaluating solid waste physical/chemical methods, SW846 Method 3050B: Acid digestion of sediments, sludges, and soils. USEPA, office of solid waste

Watts DB, Torbert HA (2011) Long-term tillage and poultry litter impacts on soybean and corn grain yield. Agron J 103:1479-1486. doi:10. 2134/agronj2011.0073

Wild PL, van Kessel C, Lundberg J, Linquist BA (2011) Nitrogen availability from poultry litter and pelletized organic amendments for organic rice production. Agron J 103:1284-1291. doi:10.2134/ agronj2011.0005

Young K, Carreire RI, Goodwin HL, Wailes E (2005) Economics of transporting poultry litter from northwest Arkansas to eastern Arkansas croplands. Paper presented at the Southern Agricultural Economics Association Meetings in Little Rock, Arkansas, 5-9 February 2005 